
УДК 616-002.182

DOI 10.11603/1811-2471.2020.v.i1.11070

\title{
КЛІНІЧНИЙ ВИПАДОК САРКОЇДОЗУ ЛЕГЕНЬ 3 КОМПЛЕКСНОЮ МІЖДИСЦИПЛІНАРНОЮ ВЕРИФІКАЦІЄЮ ДІАГНОЗУ
}

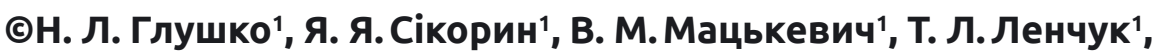 \\ Ю. О. Мицик' ${ }^{2}$ В. М. Рижик ${ }^{1}$

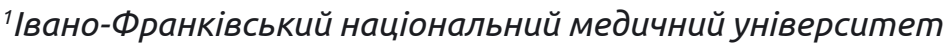 \\ ${ }^{2}$ Львівський національний медичний університет імені, Данила Галицького
}

РЕЗЮМЕ. Ідіопатичне виникнення, різноманітність клінічних проявів, неможливість спрогнозувати перебіг саркоїдозу потребує максимального розгляду всіх підтверджених випадків саркоїдозу з метою точного підбору стратегії терапії.

Матеріал і методи. Описаний випадок діагностики та верифікації саркоїдозу легень за допомогою різних методів обстеження до та після лікування задля об'єктивного висвітлення можливостей кожного виду діагностики.

Результати. Розглянутий клінічний випадок саркоїдозу у пацієнта 45 років, продемонстровано важливість поєднання сучасних методів обстеження, в тому числі комп'ютерної томографії, полімеразно-ланцюгової реакції в дослідженні харкотиння, визначення ангіотензинперетворюючого ферменту, відеобронхоскопії, біопсії лімфатичного вузла та інших у верифікації діагнозу.

Висновки. Застосування комплексного підходу в діагностиці легеневого саркоїдозу дозволяє не тільки верифікувати, а й простежити динаміку патологічного процесу під впливом призначених лікувальних заходів та оптимально скоригувати дозування глюкокортикостероїдної терапії.

КЛючовІ СЛОВА: саркоїдоз; відеобронхоскопія; комп'ютерна томографія; визначення ангіотензинперетворювального ферменту; гістологічне дослідження лімфатичного вузла; глюкокортикостероїдна терапія.

Вступ. Саркоїдоз - гранулематозне захворювання із невстановленою етіологією, що уражає переважно лімфатичні вузли, легені, рідше - інші органи, та потребує нових стратегій лікування, окрім кортикостероїдів [1]. Висока побічна дія кортикостероїдних препаратів та досі незрозуміла причина виникнення й ремісії саркоїдозу $є$ основними цілями вчених у пошуку альтернативних, дієвих та менш агресивних методів лікування [2]. Частий безсимптомний перебіг саркоїдозу із самовиліковуванням $\epsilon$ причиною фіксації лише частини випадків цього захворювання. Ідіопатичне виникнення, різноманітність клінічних проявів, неможливість спрогнозувати перебіг потребує максимального розгляду усіх підтверджених випадків саркоїдозу.

Мета - опис випадку діагностики та верифікації саркоїдозу легень з використанням різних методів обстеження до та після лікування задля об'єктивного висвітлення можливостей кожного виду діагностики.

Матеріал і методи дослідження. Пацієнт Ч., 1974 року народження, у липні 2019 р. звернувся до лікаря зі скаргами на загальну слабкість, малопродуктивний кашель, пришвидшене серцебиття, пітливість, задишку при незначному фізичному навантаженні, зниження продуктивності праці. 3 анамнезу: хворіє з осені 2018 р., відколи з'явилися і почали наростати вищевказані скарги. 3 анамнезу життя: не курить, професійних шкідливостей не має. Об'єктивно: загальний стан Хво- рого відносно задовільний, збільшена надключична група лімфовузлів. Дихання везикулярне, 3 жорстким відтінком. За даними функціональних дихальних тестів - мінімальна рестрикція. Дифузія газів- 70 \%. Загальний, біохімічний аналіз крові, холтерівське моніторування електрокардіограми, ехокардіоскопія, УЗД органів черевної порожнини та малого таза, ревмопроби, глюкоза крові та аналіз сечі - без змін. За даними офтальмологічного та ЛОР-оглядів патологій не виявлено. Рiвень ангіотензинперетворювального ферменту 121 од/л (референтні значення - 12,0-68,0 од/л). GeneExpert MTB/RIF, полімеразно-ланцюгова реакція та триразове дослідження мокроти на кислотостійкі бактерії - негативні. Рентгенологічно: на прямій та боковій рентгенограмах легень двобічне розширення коренів легень за рахунок збільшення їх головок (рис. 1). Дані комп'ютерної томографії органів грудної клітки: вузликові зміни легень та лімфаденопатія середостіння (рис. 2). За результатами відеобронхоскопії: вхід у трахею вільний, трахея без змін. Слизова бронхіального дерева гіперемійована, набрякла (рис. 3). При дослідженні бронхоальвеолярного змиву цитологічно: ознак атипії не виявлено, вогнищевий нейтрофільоз. Результат патогістологічного дослідження біопсії тканини лімфатичного вузла надключичної групи справа № 18185-87: тканина лімфатичного вузла зі стертим малюнком за рахунок склеротичних змін гранулематозного запалення зі злиттям горбиків, формуванням вогнищ гіаліно- 
Огляди літератури, оригінальні дослідження, погляд на проблему, випадок з практики, короткі повідомлення зу, що може відповідати саркоїдозу та потребує уточнення в спеціалізованому центрі. При консультативному перегляді препаратів № 2 6770/19: у тканині лімфовузла численні епітеліоїдноклітинні гранульоми продуктивного, «штампованого» характеру, з поодинокими гігантськими багатоядерними клітинами типу Лангханса, морфологія яких характерна для саркоїдозу (рис. 4). Відначається клінічна невідповідність ступенів задишки і тахіпное та рівня ураження легень. Встановлено діагноз: саркоїдоз органів дихання II стадії, фаза стабілізації, легенева недостатність II ступеня. Пацієнту було рекомендовано провести

курс глюкокортикостероїдної терапії метилпреднізолоном у дозі 24 мг на добу. Через 3 місяці було повторно проведено загальний аналіз крові, ехокардіоскопію на предмет виявлення можливої легеневої гіпертензії, рентгенографію та комп'ютерну томографію органів грудної клітки - відзначено позитивну динаміку. Пацієнту обрано підтримувальний курс глюкокортикостероїдних препаратів із поступовим зниженням пероральних та додатковим призначенням інгаляційного будесоніду/формотеролу 160/4,5 мкг по 1 інгаляції вранці (враховуючи скарги пацієнта на безсоння), препарати калію, кальцію.

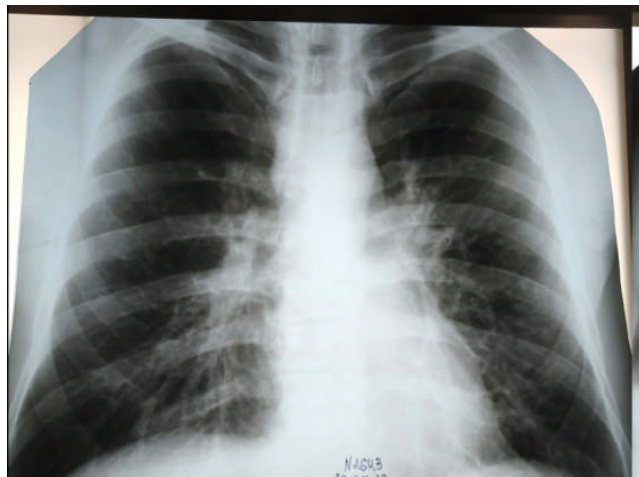

$a$

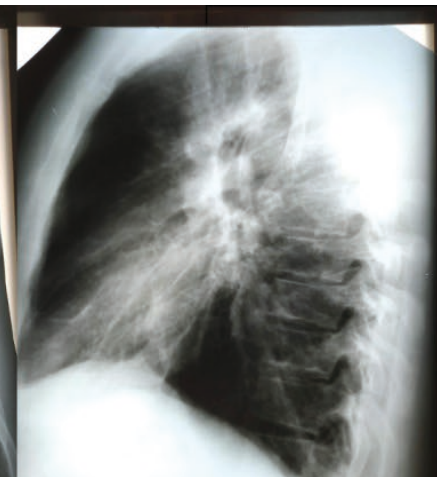

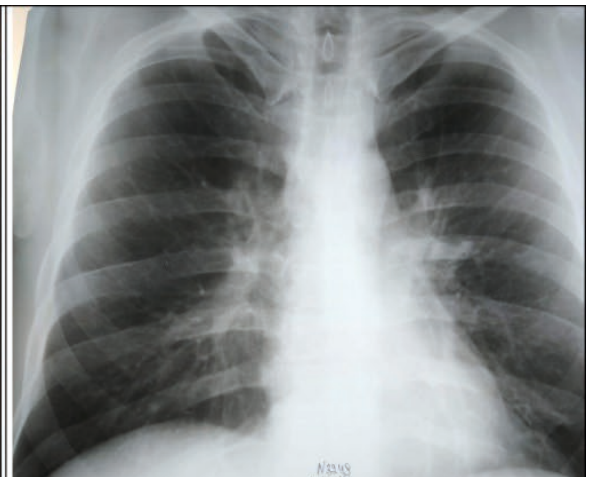

6

Рис. 1. Рентгенограми органів грудної клітки у прямій та боковій проекціях: а) до лікування відзначається двобічне розширення коренів легень за рахунок збільшення бронхопульмональних лімфатичних вузлів; 6) після лікування - рентгенологічна динаміка позитивна - зменшення у розмірі головок коренів лімфатичних вузлів.

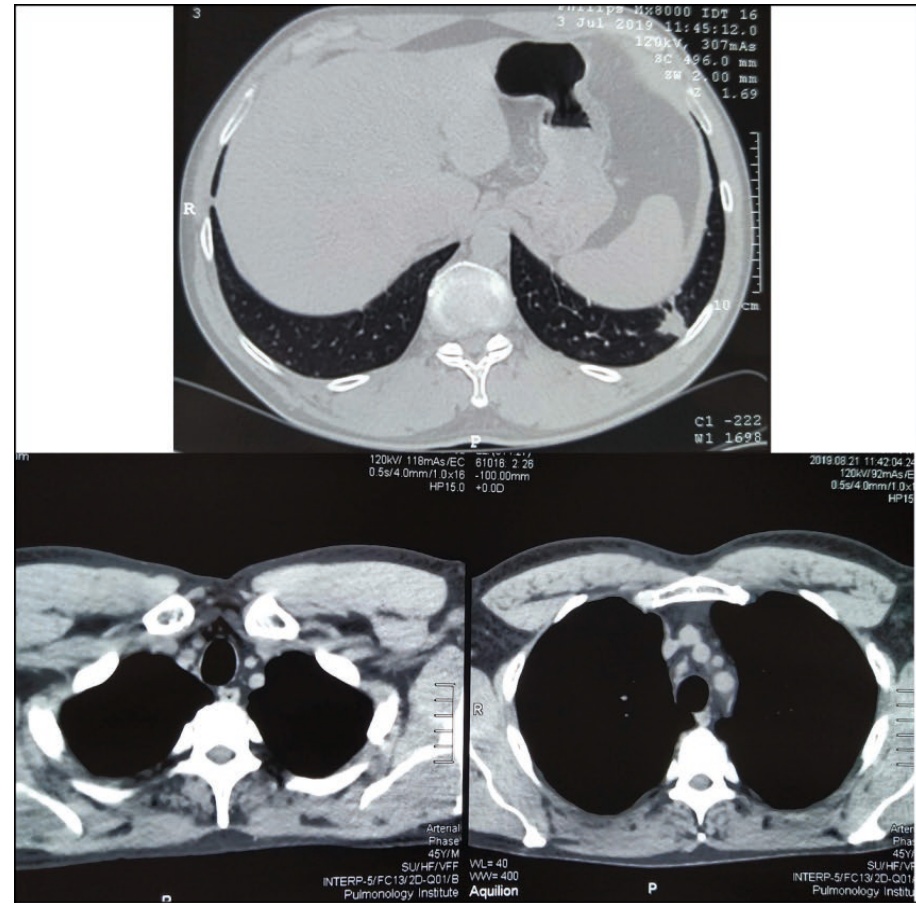

a

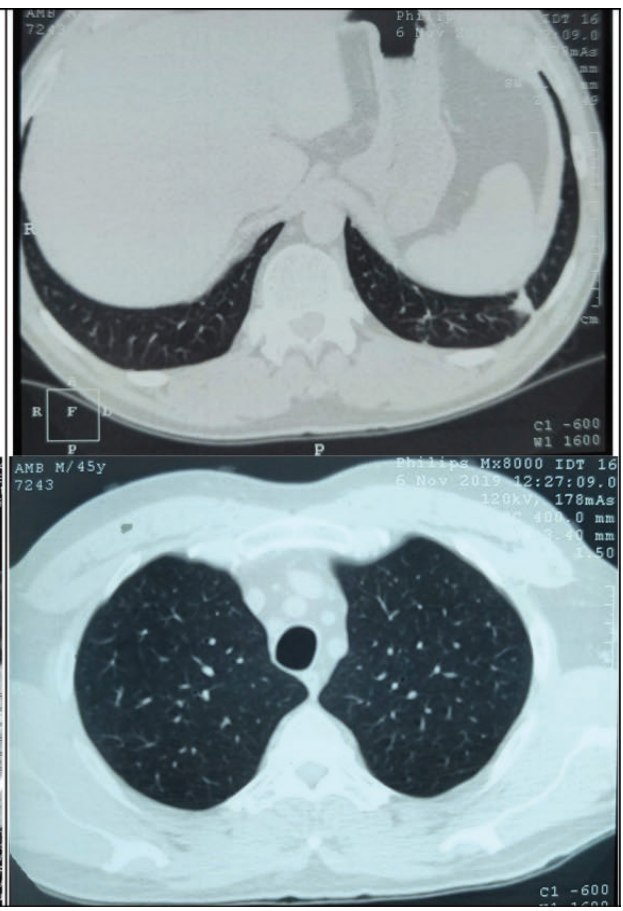

6

Рис. 2. Комп'ютерно-томографічні поперечні зрізи органів грудної клітки: а) до лікування - у IX сегменті зліва вузол та збільшення верхніх паратрахеальних лімфовузлів; б) після лікування-позитивна КТ-динаміка: зменшення вузла та лімфовузів. 
Огляди літератури, оригінальні дослідження, погляд на проблему, випадок з практики, короткі повідомлення

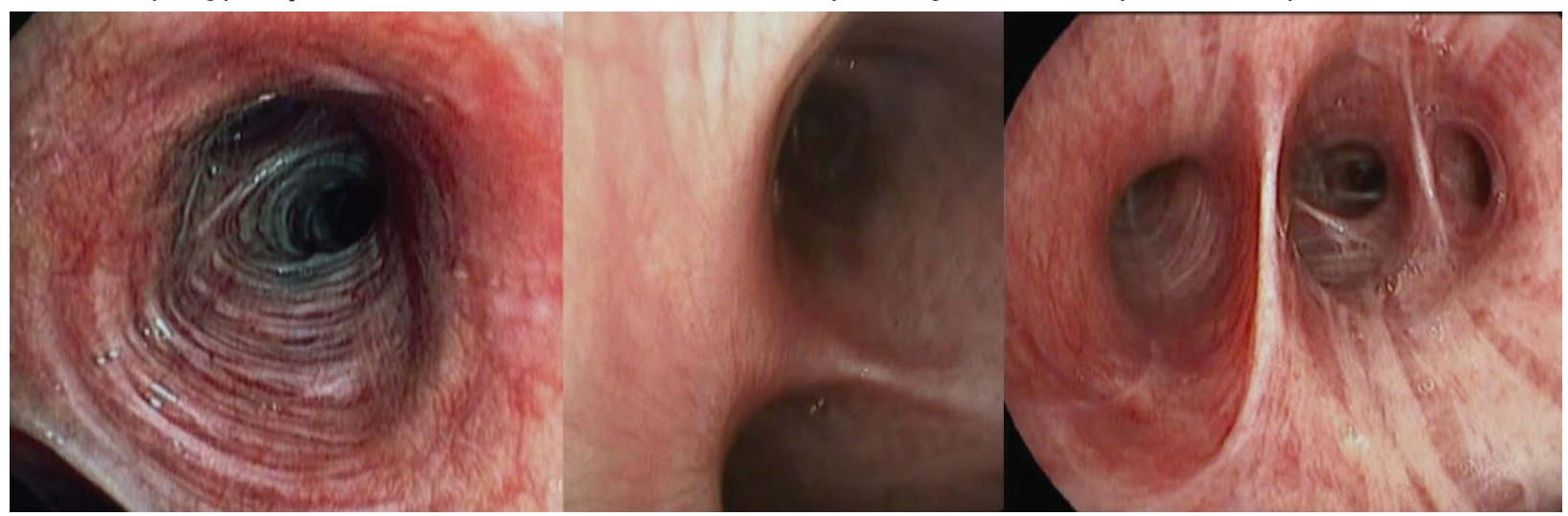

Рис. 3. Фрагменти проведеної відеобронхоскопії: слизова гіперемійована. Прохідність трахеобронхіального дерева збережена.

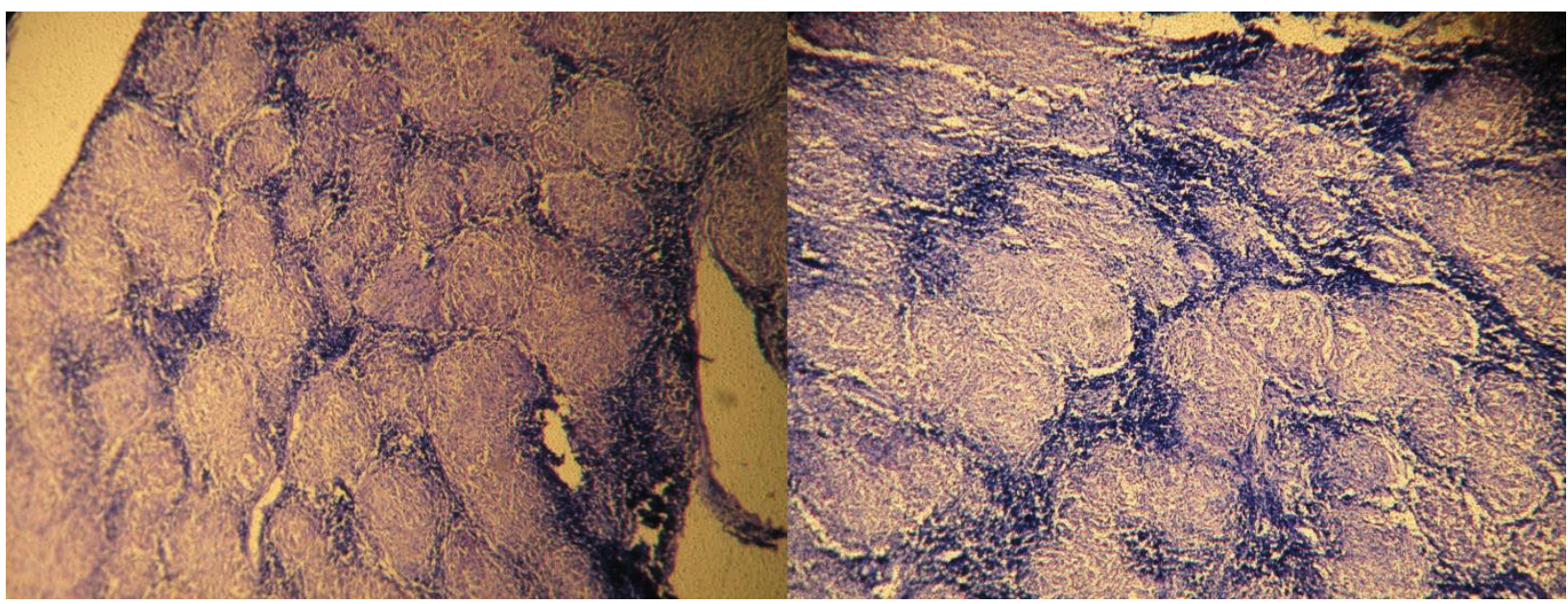

Рис. 4. Мікрофотографії гістоструктури надключичного лімфовузла. Картина лімфовузла із стертим малюнком, гранульоматазним ураженням, з наявністю гігантських багатоядерних клітин Лангханса, що відповідає саркоїдозу. Забарвлення гематоксилінм-еозином. 36. ок. 10. о6. 20.

Від пацієнта отримано письмову інформовану згоду на опрацювання отриманих даних на підставі конфіденційної обробки інформації. Під час проведення діагностичного обстеження було дотримано етичних принципів медичних досліджень за участю людини згідно з Гельсінською декларацією Всесвітньої медичної асоціації.

Результати й обговорення. До сьогодні вивчаються всі ланки патогенезу легеневого саркоїдозу, включаючи природу його антигену, роль білка сироваткового амілоїду А, значення виснаження імунних клітин та інших факторів, що сприяють змінам вродженого імунітету та формують адаптаційні профілі Т-лімфоцитів, а також те, як ці механізми впливають на підтримання гранулематозного запалення при саркоїдозі та призводять до фіброзу легень [3]. Досить добре зафіксовано участь В-клітин у саркоїдозі, але досі нічого не відомо про роль фолікулярних Т-хелперів при цій хворобі - головній допоміжній підгрупі Т-клітин, яка вважається причетною до гуморальної адаптаційної імунної відповіді [4]. Згідно з даними American Journal of Roentgenology, враховуючи відсутність патогномонічних скарг, рентгенологічний висновок саркоїдозу слід описувати, виключивши інші альтернативні варіанти [5]. Незважаючи на високу точність результатів комбінації підвищених рівнів ангіотензинперетворювального ферменту та хітотріодази, встановлення діагнозу саркоїдозу найчастіше вимагає біопсії та гістопатологічної оцінки, оскільки не існує єдиного маркера, що має достатню специфічність та чутливість для верифікації захворювання [6]. Вивчення утворення гранульоми та формування іï імунних реакцій $\epsilon$ загадкою, головним чином тому, що вони розвиваються у віддалених місцях, що робить отримання відповідних біологічних показників складним. Тому дослідники для отримання більшого розуміння вдаються до використання математичних та обчислювальних підходів 
Огляди літератури, оригінальні дослідження, погляд на проблему, випадок з практики, короткі повідомлення для з'ясування механізмів, що сприяють утворенню та функції гранульом і прогресуванню захворювань. Однак використання математичного моделювання для детального пояснення нетуберкульозних інфекцій все ще є первинним [7]. Враховуючи, що з часу офіційного виходу постанови Американського торакального товариства Європейського респіраторного товариства та Всесвітньої асоціації саркоїдозу та інших гранулематозних розладів (WASOG) у 1999 р. (щодо встановлення діагнозу саркоїдозу тоді, коли рентгенологічні результати підтверджуються гістологічними знахідками неказеозних гранульом у зразку біопсії та інші причини гранульом можуть бути виключеними) відбувся значний прогрес у вивченні невідомих раніше ланок патогенезу саркоїдозу і на сьогодні тривають обговорення та клінічні дослідження щодо ймовірності розробки високоточного діагностичного тесту на основі конкретних механізмів захворювання, який би міг стати альтернативою травматичній, болючій, інвазивній процедурі обстеження $[8,9]$. Постійно удосконалюються протоколи терапії саркоїдозу легень на основі персоніфікованого підходу, починаючи від випадків, при яких лікування не $\epsilon$ необхідним, і закінчуючи

пацієнтами, рефрактерними до усіх трьох ліній лікування (кортикостероїди, антиметаболіти, моноклональні антитіла до фактора некрозу пухлин- $\alpha$ ), для яких єдиним методом залишається трансплантація легень [10]. Терапія кортикостероїдами пов'язана з токсичними ефектами, які співвідносяться як із кумулятивною дозою, так і з тривалістю лікування. Дефіцит як справді ефективних методів терапії, так і надійних прогнозів непередбачуваного розвитку хвороби у окремих пацієнтів значною мірою робить саркоїдоз таким складним для керованого моніторингу із прогностично сприятливим результатом [11]. Постійно нові дані різних лабораторних досліджень залишають ще багато питань без відповіді щодо патогенезу саркоїдозу і передбачення його розвитку та створюють нові напрямки для подальших клінічних досліджень і стратегій лікування.

Висновки. Застосування комплексного підходу в діагностиці легеневого саркоїдозу дозволяє не тільки верифікувати, а й простежити динаміку патологічного процесу під впливом призначених лікувальних заходів та оптимально скоригувати дозування глюкокортикостероїдної терапії.

\section{ЛІТЕРАТУРА}

1. The NLRP3 inflammasome pathway is activated in sarcoidosis and involved in granuloma formation [Electronic resource] / C. Huppertz, B. Jäger, G. Wieczorek [et al.] // European Respiratory Journal. - 2020. - URL : https://doi. org/10.1183/13993003.00119-2019.

2. Bosentan for patients with steroid-resistant pulmonary sarcoidosis: A randomised controlled trial [Electronic resource] / K. E.Hostettler, F. Baty, R. Kleiner [et al.] // Swiss Medical Week. - 2018. - Vol. 148. - URL : https://doi. org/10.4414/smw.2018.14677.

3. Patterson K. C. The pathogenesis of pulmonary sarcoidosis and implications for treatment [Electronic resource] / K. C. Patterson, E. S. Chen // Chest. - 2018. Vol. 153 (6). -P. 1432-1442. - URL: https://doi.org/10.1016/ j.chest.2017.11.030.

4. Crotty S. T Follicular helper cell biology: A decade of discovery and diseases [Electronic resource] / S. Crotty // Immunity. - 2019. - Vol. 50 (5). - P. 1132-1148. - URL : https://doi.org/10.1016/j.immuni.2019.04.011.

5. Sarcoidosis: A diagnosis of exclusion [Electronic resource] / G. M. Lee, K. Pope, L. Meek, [et al.] // American Journal of Roentgenology. - 2020. - Vol. 214 (1). - P. 5058. - URL : https://www.ajronline.org/doi/abs/10.2214/ AJR.19.21436.

6. Combined application of angiotensin converting enzyme and chitotriosidase analysis improves the laboratory diagnosis of sarcoidosis [Electronic resource] / A. Enyedi, A. Csongrádi, I. T. Altorjay [et al.] // Clinica Chi-

mica Acta. - 2020. - Vol. 500. - P.155-162. - URL : https:// doi.org/10.1016/j.cca.2019.10.010.

7. Magombedze G. Mathematical and computational approaches in understanding the immunobiology of granulomatous diseases [Electronic resource] / G. Magombedze, S. Marino // Current Opinion in Systems Biology. - 2018. Vol. 12. - P. 1-11. - URL : https://doi.org/10.1016/j. coisb.2018.07.002.

8. Costabel U. ATS/ERS/WASOG statement on sarcoidosis. Sarcoidosis Statement Committee. American Thoracic Society. European Respiratory Society. World Association for Sarcoidosis and Other Granulomatous Disorders [Electronic resource] / U. Costabel, G. W. Hunninghake // European Respiratory Journal. - 1999. - Vol. 14. - P. 735-737. URL : https://doi.org/10.1034/j.1399-3003.1999.14d02.x.

9. Judson M. A. The diagnosis of sarcoidosis [Electronic resource] / M. A. Judson // Current Opinion in Pulmonary Medicine. - 2019. - Vol. 25 (5). - P. 484-496. URL : https://doi.org/10.1097/MCP.0000000000000596.

10. Aryal S. Contemporary optimized practice in the management of pulmonary sarcoidosis [Electronic resource] / S. Aryal, S. D. Nathan // Therapeutic advances in respiratory disease. - 2019. - Vol. 13. - URL : https://dx.doi.org/ $10.1177 \% 2 F 1753466619868935$.

11. Spagnolo P. Pulmonary sarcoidosis [Electronic resource] / P. Spagnolo, G. Rossi, R. Trisolini [et al.] // The Lancet. Respiratory Medicine. - 2018. - Vol. 6 (5). - P. 389-402. URL : https://doi.org/10.1016/S2213-2600(18)30064-X. 
Огляди літератури, оригінальні дослідження, погляд на проблему, випадок з практики, короткі повідомлення REFERENCES

1. Huppertz, C., Jäger, B., Wieczorek, G., Engelhard, P., Oliver, S.J., Bauernfeind F-G. et al. (2020). The NLRP3 inflammasome pathway is activated in sarcoidosis and involved in granuloma formation. European Respiratory Journal. Retrieved from:https://doi.org/10.1183/13993003.001192019.

2. Hostettler, K.E., Baty, F., Kleiner, R., Junker, L., Tamm, M., Brutsche, M.H. (2018). Bosentan for patients with steroid-resistant pulmonary sarcoidosis: A randomised controlled trial. Swiss Medical Week, 148. Retrieved from: https://doi.org/10.4414/smw.2018.14677.

3. Patterson, K.C., \& Chen, E.S. (2018). The pathogenesis of pulmonary sarcoidosis and implications for treatment. Chest, 153 (6), 1432-1442. Retrieved from: https:// doi.org/10.1016/j.chest.2017.11.030.

4. Crotty, S. (2019). T follicular helper cell biology: A decade of discovery and diseases. Immunity, 50 (5), 11321148. Retrieved from: https://doi.org/10.1016/j.immuni.2019.04.011.

5. Lee, G.M., Pope, K., Meek, L., Chung, J.H., Hobbs, S.B., \& Walker, C.M. (2020). Sarcoidosis: A diagnosis of exclusion. American Journal of Roentgenology, 214 (1), 50-58. Retrieved from: https://www.ajronline.org/doi/abs/10.2214/ AJR.19.21436.

6. Enyedi, A., Csongrádi, A., Altorjay, I.T., Beke, G.L. Váradi, C., Enyedi, E.E. et al. (2020). Combined application of angiotensin converting enzyme and chitotriosidase

analysis improves the laboratory diagnosis of sarcoidosis. Clinica Chimica Acta, 500, 155-162. - Retrieved from: https://doi.org/10.1016/j.cca.2019.10.010.

7. Magombedze, G., \& Marino, S. (2018). Mathematical and computational approaches in understanding the immunobiology of granulomatous diseases. Current Opinion in Systems Biology, 12, 1-11. Retrieved from: https://doi. org/10.1016/j.coisb.2018.07.002.

8. Costabel, U., \& Hunninghake, G.W. (1999). ATS/ERS/ WASOG statement on sarcoidosis. Sarcoidosis Statement Committee. American Thoracic Society. European Respiratory Society. World Association for Sarcoidosis and Other Granulomatous Disorders. European Respiratory Journal, 14, 735-737. Retrieved from: https://doi.org/10.1034/ j.1399-3003.1999.14d02.x.

9. Judson, M.A. (2019). The diagnosis of sarcoidosis. Current Opinion in Pulmonary Medicine, 25 (5), 484-496. Retrieved from: https://doi.org/10.1097/MCP.0000000000000596.

10. Aryal, S., \& Nathan, S.D. (2019). Contemporary optimized practice in the management of pulmonary sarcoidosis. Therapeutic Advances in Respiratory Disease, 13. Retrieved from: https://dx.doi.org/10.1177\%2F1753466619868935.

11. Spagnolo, P., Rossi, G., Trisolini, R., Sverzellati, N., Baughman, R.P., Wells, A.U. (2018). Pulmonary sarcoidosis. The Lancet. Respiratory Medicine, 6 (5), 389-402. Retrieved from: https://doi.org/10.1016/S2213-2600(18)30064-X.

\title{
КЛИНИЧЕСКИЙ СЛУЧАЙ САРКОИДОЗА ЛЕГКИХ С КОМПЛЕКСНОЙ МЕЖДИСЦИПЛИНАРНОЙ ВЕРИФИКАЦИЕЙ ДИАГНОЗА
}

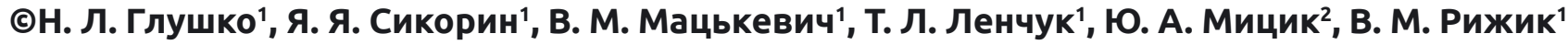 \\ 1 Ивано-Франковский национальный медицинский университет \\ ${ }^{2}$ Львовский национальный медицинский университет имени Данила Галицкого
}

РЕзЮМЕ. Идиопатическое возникновение, разнообразие клинических проявлений, невозможность спрогнозировать течение саркоидоза требуют максимального рассмотрения всех подтвержденных случаев саркоидоза с целью точного подбора стратегии терапии.

Материал и методы. Описан случай диагностики и верификации саркоидоза легких с помощью различных методов обследования до и после лечения для объективного освещения возможностей каждого вида диагностики

Результаты. Рассмотрен клинический случай саркоидоза у пациента 45 лет, продемонстрирована важность сочетания современных методов обследования, в том числе компьютерной томографии, полимеразной цепной реакции в исследовании мокроты, определения ангиотензинпревращающего фермента, видеобронхоскопии, биопсии лимфатического узла и других для верификации диагноза.

Выводы. Применение комплексного подхода в диагностике легочного саркоидоза позволяет не только верифицировать, но и проследить динамику патологического процесса под влиянием назначенных лечебных мероприятий и оптимально скорректировать дозировку глюкокортикостероидной терапии.

КЛЮЧЕВЫЕ СЛОВА: саркоидоз; видеобронхоскопия; компьютерная томография; определение АПФ; гистологическое исследование лимфатического узла; глюкокортикостероидная терапия. 
Огляди літератури, оригінальні дослідження, погляд на проблему, випадок з практики, короткі повідомлення

CLINICAL CASE OF LUNG SARCOIDOSIS WITH INTEGRATED INTERDISCIPLINARY

DIAGNOSIS VERIFICATION

@N. L. Glushko1, Ya. Ya. Sikorin', V. M. Matskevich', T. L. Lenchuk'1, Yu. O. Mytsyk², V. M. Rizhik¹

${ }^{1}$ Ivano-Frankivsk National Medical University

${ }^{2}$ Danylo Halytskyi Lviv National Medical University

SUMMARY. The idiopathic onset, the variety of clinical manifestations, the inability to predict the course requires the maximum consideration of all confirmed cases of sarcoidosis in order to accurately select a therapy strategy.

Material and Methods. Description of diagnostic and verification pulmonary sarcoidosis using different methods of examination before and after treatment for objective reporting capabilities of each type of diagnosis.

Results. The clinical case of sarcoidosis in a 45 year-old patient is considered, the importance of combining modern methods of examination, including computed tomography, polymerase-chain reaction in the study of sputum, determination of angiotensin-converting enzyme, video bronchoscopy, and biopsy of lymph node are demonstrated.

Conclusions. The use of a comprehensive approach in the diagnosis of pulmonary sarcoidosis can not only verify but also trace the dynamics of the pathological process under the influence of prescribed therapeutic measures and optimally adjust the dosage of glucocorticosteroid therapy.

KEY WORDS: sarcoidosis; bronchoscopy; computed tomography; determination of angiotensin-converting enzyme; histological examination of lymph node; glucocorticosteroid therapy.

Отримано 06.02.2020 